of the Biochemical Society and Section I (Physiology and Biochemistry) of the Association, to consider the financing of biochemical research in Britain (see Nature, 188, 194; 1960). Because of their wide interest, the Biochemical Society has now published the proceedings of this meeting (The Organization and Financing of Research in Bio. chemistry and Allied Sciences in Great Britain. Edited by K. S. Dodgson. Pp. 51. London: The Biochemical Socioty, 1960. 2s. 6d.). Nine speakers were chosen, who were particularly concerned with the organizing and financing of biochemical research in Britain. After an introduction by Prof. A. Haddow, the role of the following organizations was described : Medical Research Council (Dr. F. J. C. Herrald), Agricultural Research Council (Sir William Slater), Department of Scientific and Industrial Research (Mr. C. Jolliffe), and the Imperial Cancer Research Fund (Dr. G. F. Marrian). Prof. F. C. Happold discussed problems of a university department of biochemistry, Dr. F. A. Robinson dealt with bio. chernical research in industry, and Dr. J. B. Bateman discussed American support of biochemical research in Great Britain. Prof. A. Neuberger summarized the procoedings of the meeting.

\section{The Commonwealth Forestry Bureau, Oxford}

The work of the Commonwealth Forestry Bureau at Oxford has been described and published as an example of the work done by the Commonwesith Agriculturel Bureaux, of which it is the youngest member ( $A$ Synopsis of the Work and Growth of the Commonwealth Forestry Bureau, Oxford, 1939-1959. Pp. 27. Oxford: Commonwealth Forestry Bureau, 1960. 28. 6d.). The Buroau was formed in 1939 to serve foresters, wood technologists and scientists in associated fiolds throughout tho Commonwerlth, but from the first tho quarterly publication, Forestry Abstracts, attracted subscriptions from foreign countries, and the Bureau and its periodical are now internationally known; the abstracts reach more then ninety countries. The principal work of the Bureau is the quarterly publication of Forestry Abstracts, which notices, by abstract or by titlo only, more than 5,000 publications annually on forestry and associated subjects.

\section{Medicine and Public Health in China}

IN a paper presented at the meoting of tho American Association for the Advancoment of Science on December 27, Dr. William Y. Chen, U.S. Public Health Service, discussed the condition of medicine and public health in modern China. The main sources of information for the preparation of the paper were various medical and public health journals published both in Chinese and English during the past ten years. The picture is presented against the background of medicine and public health in pre-Communist China, and shows that the most remarkablo accomplishment has been the prevention and control of many infectious and parssitic diseases which have ravaged the country for genera. tions. Thero has also been an improvement in medical oducation in quantity if not in quality. Other progress in medicine does not seem to correspond with the claims mado for it.

\section{Problems in Cybernetics}

A valuable new addition to the steadily growing list of translated Russian scientific joumals has recently appeared; it is called Problems in Cybernetics (Pergamon Press. Pp. $\mathrm{x}+314$. Russian editor, A. A. Lyapunov), and it is to bo published at irregular intervals. The first issue contains a general article by Lyapunov, entitled "Certain General Problems in Cybernetics", which serves to show just what fields of inquiry the Russians include under the term 'cybernetics' at present (for the boundaries are very nebulous). Particular emphasis seorns to be placed on automatic computer programming, for the simulation of all types of control process, including those analogous to certain biological processes; on ropresentation of information and its processing, including that in automatic programme-controlled computers; on mechanization of various thought-like processes, as in decision making, recognition, strategy and various 'goal-seeking' operations. It is planned that the journal will contain, in the future, articles dealing with the theory of algorithms and automatic devices, theory of control and problems of production automation, theory of operations and of calculating machines, and with certain applications of the ideas of cybernotics to biology, econom:es and linguistics. Also, material will be included of a critical, biblio. graphical and historical nature, being primarily dotails of the work of the cybernetics seminar held in the University of Moscow. Particular reference is made to this sominar, which has been hold since 1955, with a list of titles of papers; these include work on conditionod reflexes primarily. There are also listed titles of papers read at a technical conference held in 1957 which suggest wider fields of interest; ospecially applications to linguistics, to automatic translation, to coding of chomical formulæ, to speech analysis, to machine-reading, together with many technological aspects of computer design.

\section{The Association of Universities of the British Commonwealth}

The roport of the Executive Council of the Association of Universitios of the British Commonwealth for the year ended July 31, 1960, rocords a nembership of 103 universities, 17 university colleges and 4 other approved institutions of higher loarning (Pp. 30. London: Association of Universities of the British Commonwerlth, 1960). The volume of appointmonts work continued to increase, and, in one way or another, the Association helped with 877 vacant posts and dosit, mainly by correspondence, with 4,782 inquiries; 1,514 applications woro recoived and the universities announced the appointment of 139 of the candidates who applied through the Association; of these 72 were in Australia, 28 in Now Zesland and 20 in Hong Kong. Some account is given of the Association's work under the Commonwoalth Scholarship and Fellowship Plan, and of its administration of the Frank Knox Momorial fellowships, the Marshall scholarships, the Imperial Relations Trust scholarships and of the Commonwealth University Interchange, as, for example, in connexion with the new scholarship scheme of the Drapers' Company to onable British schoolboys to take their first degreas at certain overseas Commonwealth universities. Some account of the work of the Committeo of Vice-Chancellors and Principals of the Universities of the United Kingdom is ap. pended, together with the accounts of the Associstion, and a note on the financial statement which records total expenditure of $£ 48,089$ and income of $£ 52,187$. 